\title{
Mice with pituitary tumor transforming gene (pttg) knockout demonstrate increased urinary space in renal corpuscles
}

\author{
O. Yu. Varyvoda ${ }^{1}$, A. M. Yashchenko ${ }^{1}$, A. D. Lutsyk ${ }^{1}$, R. O. Bilyy ${ }^{1,2}$, \\ S. V. Afanasiev ${ }^{2}$, Ye. Z. Filyak ${ }^{2}$, R. S. Stoika ${ }^{2}$ \\ ${ }^{1}$ Danylo Halytsky Lviv National Medical University \\ 69, Pekarska Str., Lviv, Ukraine, 79010 \\ ${ }^{2}$ Institute of Cell Biology, NAS of Ukraine \\ 14/16, Drahomanov Str., Lviv, Ukraine, 79005 \\ lutsyk@meduniv.lviv.ua
}

\begin{abstract}
Aim. To investigate the effect of knockout of the pituitary tumor transforming gene (pttg-1) on the morphometric parameters and carbohydrate determinants of the murine renal structures. Methods. Kidneys of the knockout mice in comparison with the wild type mice of BL6/C57 strain of 1 month and 1 year age were subjected to morphometric investigation and lectin histochemistry. Morphometric study was completed using ImagePro Plus and ImageJ software. Glycoconjugates were detected by means of 8 lectins possessing different carbohydrate affinities. Results. Knockout of the pttg-1 gene was accompanied by an increased (approx. 30\%) urinary space within the renal corpuscles, enhanced exposure of the LCA and PNA receptor sites, and reduced binding of the LABA, WGA and SNA lectins. Conclusions. This study suggests the effect of the pttg-1 gene products on processing and exposure of the carbohydrates in renal tissues, apparently affecting ultrafiltration of the primary urine.
\end{abstract}

Keywords: knockout of pttg-1 gene, lectin histochemistry, renal corpuscles, morphometry, mice.

Introduction. The increased expression of the pituitary tumor transforming gene ( $p t t g-1)$ and elevated amount of its protein product, securin, are currently believed to be the most characteristic signs of pituitary adenomas, as well as a wide variety of other tumors in mammals, including humans [1-3].

To elucidate a physiological role of $p t t g-1$, the line of mice with a knockout $(\mathrm{KO})$ of this gene was created [4]. The mice deficient in the pttg-1 gene exposed a disrupted spermatogenesis, thrombocytopoiesis, erythropoiesis, and damaged key parts of the immune defense [4-6].

Search for the proteins involved in the regulation of sister chromatids separation during mitosis permitted to reveal a regulatory protein securin [7] which turned out to be a product of the pttg gene [1]. It was established

(C) Institute of Molecular Biology and Genetics, NAS of Ukraine, 2014 that the fzy and fzr proteins assisted in securin ubiquitination, triggering its cleavage in the proteasome and launch of the anaphase in mitosis [8]. The securin synthesis starts in the G1 and S phases of the cell cycle, and its concentration reaches a maximum in the phase G2/ $\mathrm{M}$, significantly decreasing during mitosis. The securin over-expression causes an arrest of the cell cycle in the G2/M phase [9] and an apoptosis dependent upon the protein $\mathrm{p} 53$ [10].

The pttg- 1 knockout in mice leads to the structural changes in organs of the immune system, in particular, hyperplasia of thymus and spleen [4]. The cytological studies revealed that the $p t t g-1$ deficient fibroblasts are characterized by an increased ratio of chromosomal aberrations, polyploidy and aneuploidy, and $6 \%$ of these cells undergo apoptosis [11].

We were the first to investigate the glycan profiles of tissues and organs of the pttg- 1 knockout mice [12]. 
Primers used for mice genotyping pttg gene and its insert

\begin{tabular}{|c|c|}
\hline \multicolumn{2}{|c|}{ Primer } \\
\hline Direct & Revers \\
\hline \multicolumn{2}{|c|}{ Gene pttg } \\
\hline 5'-TAGGCTTTTCGGCAACTCTGT-3' & 5'-TTCTGGGGACTGAATTCAGG-3' \\
\hline \multicolumn{2}{|c|}{ Insert } \\
\hline 5'-GTGCTACTTCCATTTGTCACGTCC-3' & 5'-TTAGCTGTGAGCTCGTCGTG-3' \\
\hline
\end{tabular}

It is known that the carbohydrate determinants of glycoconjugates due to specific conformation, mass, charge, and other properties of their molecules, might be involved in a large variety of physiological and pathological processes [13-15]. The carbohydrate-binding proteins, lectins, are currently considered to be the most sensitive tools that are used to study the histopathological changes in cellular and tissue glycomes [15-21].

In our previous investigation [12], an increased exposure of the DGalNAc carbohydrate determinants in kidney and testes of the pttg-1 knockout mice one month of age was detected. Earlier, we showed that apoptotic processes are characterized by a significant rearrangement in cellular glycocalyx, and these data are successfully used to effectively diagnose the dying cells at the autoimmune disorders [20].

The aim of present work was to study the impact of the pttg- 1 knockout on the mouse kidney morphometric parameters, in particular, on the renal corpuscles urinary space. To get better insight into possible changes of the renal glycoconjugates, an expanded lectin panel was used. A comparison of the kidney glycan profiles in mice of 1 month and 1 year age was also accomplished.

Material and methods. Animals. BL6/C57 mice with the pttg-1 gene knockout were obtained from the Research Institute, Cedar Sinai Medical Center (Los Angeles, USA) according to the agreement on scientific cooperation with the Institute of Cell Biology, NAS of Ukraine (Lviv). 4 groups of animals were used in this study: 2 groups of the BL6/C57 wild type mice (pttg-WT) of 1 month and 1 year age, and 2 groups of animals of the same age and the same line with the pttg gene knockout ( $p t t g-\mathrm{KO})$. Each group consisted of 5 male mice, which were kept in the vivarium of the Institute of Cell Biology, NAS of Ukraine.

The investigation was carried out according to the ethical criteria for the use and handling of laboratory
Table 2

Conditions of polymerase chain reaction

\begin{tabular}{c|c|c}
\hline Stage & $t,{ }^{\circ} \mathrm{C}$ & Duration, s \\
\hline Denaturation & 94 & 60 \\
Joining primers & 58 & 60 \\
Synthesis & 72 & $\begin{array}{c}70 \text { (for TAKARA-polymerase) or } \\
100 \text { (for Taq-polymerase) }\end{array}$ \\
\end{tabular}

animals established by Lviv National Medical University in accordance with the "General ethical principles on experiments with animals» of the $1^{\text {st }}$ National Congress on Bioethics (Kyiv, 2001), and in compliance with the National Institutes of Health (NIH) Guide for the Care and Use of Laboratory Animals (1996).

Identification of the pttg- 1 gene or insertion, inverted instead of the gene in the knockout mice, was performed by the polymerase chain reaction (PCR) using the primers specific to the pttg- 1 gene or insertions (Table 1). DNA was prepared from blood cells of mice using a reagent set of «IsoGene» ( Russia).

PCR was performed using the reagents of «Fermentas» (Lithuania) according to the previously optimized program (Table 2 ), having previously denaturated mouse genomic DNA in the reaction mixture at $94{ }^{\circ} \mathrm{C}$ for 6 min. For the synthesis of sufficient DNA quantities, 32-34 cycles of the PCR were performed. At the end of the reaction last cycle, the samples were incubated at $72{ }^{\circ} \mathrm{C}$ for $7 \mathrm{~min}$ for the extension of truncated products. The PCR products were separated with electrophoresis in $1.5 \%$ agarose gels in 0.5 -fold tris-borate buffer at a voltage of $5 \mathrm{~V} / \mathrm{cm}$. The results of screening for two animals of each group are presented in Fig. 1.

Tissue samples. Mice were euthanized by an overdose of diethyl ether. Histological material (kidney) was fixed in $4 \%$ neutral formalin and embedded in paraplast, according to the standard protocol. For general 


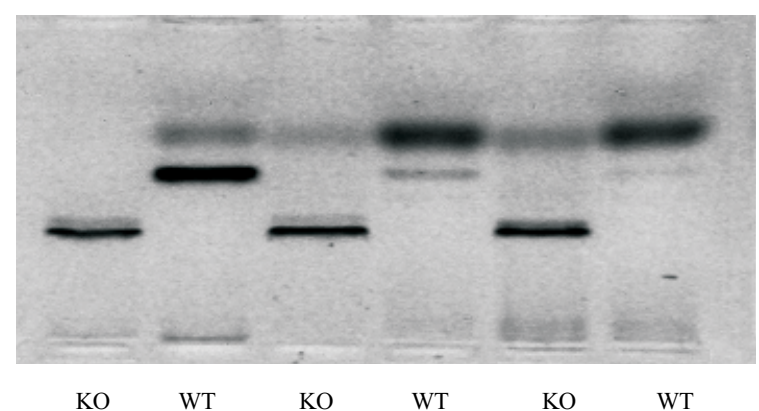

Fig. 1. Electrophoregram of PCR products of $p t t g-1$ gene knockout $(\mathrm{KO}$, 596 base pairs); WT - PCR products of pttg- 1 gene wild type (114 base pair)

Table 3

Used lectins and their carbohydrate specificity

\begin{tabular}{|c|c|c|}
\hline Lectin and its abbreviated name & Specific monosaccharide & Complementary oligosaccharidic moiety* \\
\hline Lens culinaris agglutinin (LCA) & $\alpha \mathrm{DMan} / \alpha \mathrm{DGlc}$ & $\operatorname{Man}(\alpha 1-3)$ Man, glycogen \\
\hline Laburnum anagyroides bark agglutinin (LABA) & $\alpha$ LFuc & $\operatorname{Fuc}(\alpha 1-2) \operatorname{Gal}(\beta 1-4) \mathrm{Glc}$ \\
\hline Soybean agglutinin (SBA) & DGalNAc & $\operatorname{GalNAc}(\alpha 1-3) \operatorname{Gal}(\beta 1-3)$ GalNAc \\
\hline Helix pomatia agglutinin (HPA) & $\alpha$ DGalNAc & GalNAc $(\alpha 1-3)$ GalNAc \\
\hline Peanut agglutinin (PNA) & DGal & $\operatorname{DGal}(\beta 1-3)$ GalNAc \\
\hline Ricinus communis agglutinin (RCA) & $\beta D G a l>$ NeuNAc & NeuNAc(2-6)Gal( $(\beta 1-4)$ GlcNAc \\
\hline Wheat germ agglutinin (WGA) & DGlcNAc $>$ NeuNAc & $\begin{array}{l}\text { NeuNAc(2-6)Gal( }(\beta 1-4) \text { GlcNAc, } \\
\text { Man }(\beta 1-4) \text { GlcNAc }(\beta 1-4) \text { GlcNAc }\end{array}$ \\
\hline Sambucus nigra agglutinin (SNA) & NeuNAc( $\alpha 2-6)$ DGal & $\operatorname{NeuNAc}(\alpha 2-6) \operatorname{DGal}(\beta 1-4) \operatorname{GlcNAc}(\beta 1-2)$ \\
\hline
\end{tabular}

*List of abbreviations: DMan - D-mannose; DGlc - D-glucose; LFuc - L-fucose; DGalNAc - N-acetyl-D-galactosamine; DGal - D-galactose; NeuNAc - N-acetyl-neuraminic (sialic) acid; DGlcNAc - N-acetyl-D-glucosamine.

morphology study, the sections $7 \mu \mathrm{m}$ thick were stained with hematoxylin and eosin. The pictures were taken from the received histological slides using a microscope DeltaOptical Evolution 100 Trino, equipped with a camera DeltaOptical using objective lenses $20 \times \mathrm{NA}$ 0.4 and $40 \times$ NA 0.65 .

Image analysis was carried out using ImagePro Plus and ImageJ software systems. The number of renal corpuscles was determined by counting corpuscles in the micrographs of 10 independent sections of each option (one micrograph consistent area of $0.95 \mathrm{~mm}^{2}$ ) and the mean and standard error mean were calculated. Determination of the urinary space area was carried out by analyzing urinary spaces of 100 randomly selected kidney corpuscles (a minimum of three different histological sections) with the calculation of the area defined by the object program ImagePro Plus. Statistical significance was calculated using $t$-test.

Lectin histochemistry. To study the renal glycoconjugates, 8 lectins with different carbohydrate specificity were used (Table 3 ). They were purified and conjugated with horseradish peroxidase by Dr. V. A. Antoniuk («Lectinotest Lab», Ukraine). More detailed information concerning carbohydrate specificity of the lectins used is presented in the monographs $[15,16]$.

To detect the carbohydrate determinants the deparaffinized sections were incubated for $20 \mathrm{~min}$ in methanol with $0.3 \% \mathrm{H}_{2} \mathrm{O}_{2}$ to block endogenous peroxidase; through descending ethanols adjusted to phosphate buf- 
Results and discussion. Morphometric investigation. Morphometric study of hematoxylin and eosin stained specimens revealed that in the control group the number of renal corpuscles was $17.0 \pm 0.90$, whereas in the experimental group it was $17.8 \pm 1.68$ (in the same field of observation corresponding to $0.95 \mathrm{~mm}^{2}$ ). However, the urinary space increased by 1.54 times in the experimental group (519.214 \pm 41.194 pixels $)$ comparing with the control group $(336.429 \pm 27.699$ pixels) (Fig. 2). This difference in the urinary space area was statistically significant $(\mathrm{P}=0.0002)$.

Lectin histochemistry. The LCA lectin receptor sites were localized on the luminal surface and in the apical portions of tubular epithelium, as well as within the nuclei of podocytes, endothelial and mesangial cells of the renal corpuscles (Fig. 3). The fucose-specific LABA lectin demonstrated a moderate reactivity towards parenchymal elements of the kidney, on which the background renal corpuscles were completely negative. The SBA lectin labeled heavily the luminal surface of collecting ducts, whereas the receptors sites for HPA (lectin with similar yet not identical carbohydrate affinities) were exposed on the luminal surface of the renal tubules of different types. The galactose-specific lectins PNA (Fig. 4) and RCA (Fig. 5) - demonstrated a moderate reactivity with the cytoplasmic glycoconjugates of renal tubule cells, counterstained their luminal surface, as well as the nuclei of podocytes, endothelial and mesangial cells of renal corpuscles. The WGA and SNA lectins intensely stained the basement membrane of the renal corpuscles and luminal surface of the renal tubules (Fig. 6).

We revealed an increased LCA and PNA reactivity of the renal structures in the pttg-KO mice compared to the wild-type mice with a simultaneous decrease of the LABA, WGA and SNA labeling. The lectin binding profile for SBA, HPA and RCA in the experimental animals did not differ from that in the control ones. The detected redistribution of LCA, PNA, LABA, WGA and SNA receptor sites was rather quantitative than qualitative: a visual evaluation of intensity of histochemical reactions with the grade scale ++ strong, + moderate, negative was determined by two independent investigators. However, since no qualitative changes in the lectin labeling were found, there is no direct evidence for the influence of the expression products of the pttg- 1 gene on processing and exposure of the renal glycoconjugates.

Most of the used lectins (LCA, HPA, PNA, RCA, WGA, SNA) intensely labeled luminal surface of the renal tubules, which apparently indicates the involvement of glycoconjugates with a wide range of the carbohydrate determinants in the re-absorption process. Additionally, WGA, RCA and SNA demonstrated an intense binding to the basement membrane of the renal corpuscles, the highest selectivity of binding was characteristic for WGA. These data are in good correlation with the results of Hanai et al. [23] and our previous report concerning the rat kidney [24].

A strong reactivity of WGA, RCA and SNA with the basement membrane of the renal corpuscles revealed in this study, confirmed our earlier observations on the important role of the sialoglycans and glycopolymers with the terminal DGlcNAc residues in the histophysiology of filtration barrier [24]. In our hands, the SBA lectin demonstrated rather selective affinity for the collecting duct cells, which differs from the data of Hanai et al. [23] who reported about this lectin reactivity also with the brush border of proximal tubules in murine kidney.

It should be noted that the lectin binding profiles of the renal structures of BL6/C57 mice one month and one year of age, showed no difference. This observation apparently indicates that maturation of the carbohydrate determinants in kidney of this strain of mice is completed by the $30^{\text {th }}$ postnatal day. During forthcoming eleven months the weight and size of organs increased, but the profile of carbohydrate determinants remains unchanged. Our results coincide with the Hanai et al. [23] data obtained in the ddY mice strain. Interestingly, the changes of lectin receptor sites in rat kidney continued at least until the 60th postnatal day [24].

The development and function of urinary system are closely related to those in other organ systems, therefore the signaling pathways and the partner proteins described in testes and other organs can be relevant to the renal histophysiology. It was demonstrated that the pttg-1 knockout mice remain viable and maintain major vital functions, in particular, decreased but sufficient fertility. The morphology of some internal organs was changed in these animals, including thymic hyperplasia in combination with hypoplasia of spleen and tes- 

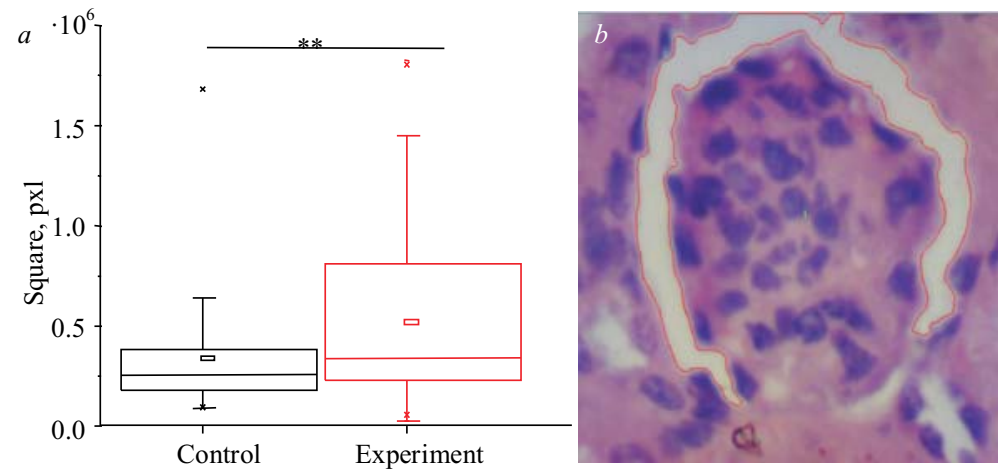

Fig. 2. Urinary space area in control (pttgWT) and experimental (pttg-KO) mice calculated for 100 renal corpuscles $(a)$; urinary space image (red outline) of control $(b)$ and experimental $(c)$ mouse
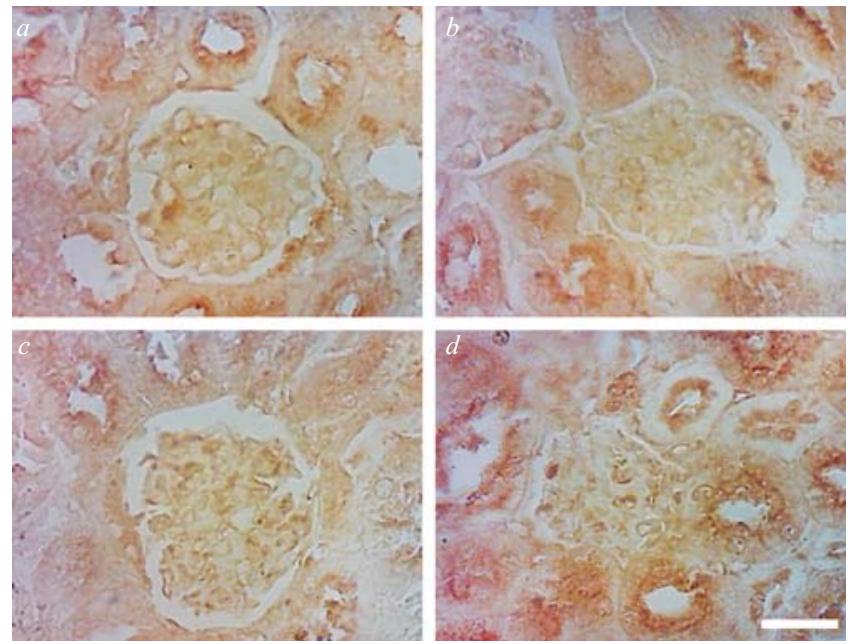

Fig. 3. LCA binding in the kidneys of mice aged 1 month $(a, b)$ and 1 year $(c, d)$ : increased reactivity of brush border in renal tubules of $p t t g-$ KO mice $(b, d)$ compared to pttg-WT $(a, c)$ animals. Objective $40 \times$, scale bar $20 \mu \mathrm{m}$
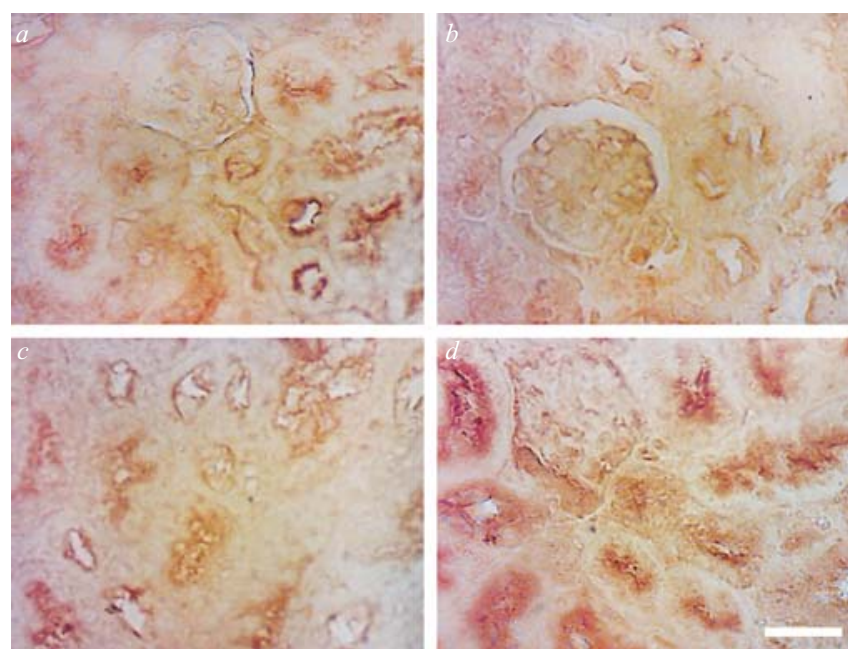

Fig. 5. Accumulation of RCA-reactive glycoconjugates in the brush border of renal tubules, basement membrane of renal corpuscles: $p t t g-$ WT $(a, c)$ and $p t t g-\mathrm{KO}(b, d)$, animals 1 month $(a, b)$ and 1 year $(c, d)$ of age. No significant differences between different group animals. Objective $40 \times$, scale bar $20 \mu \mathrm{m}$
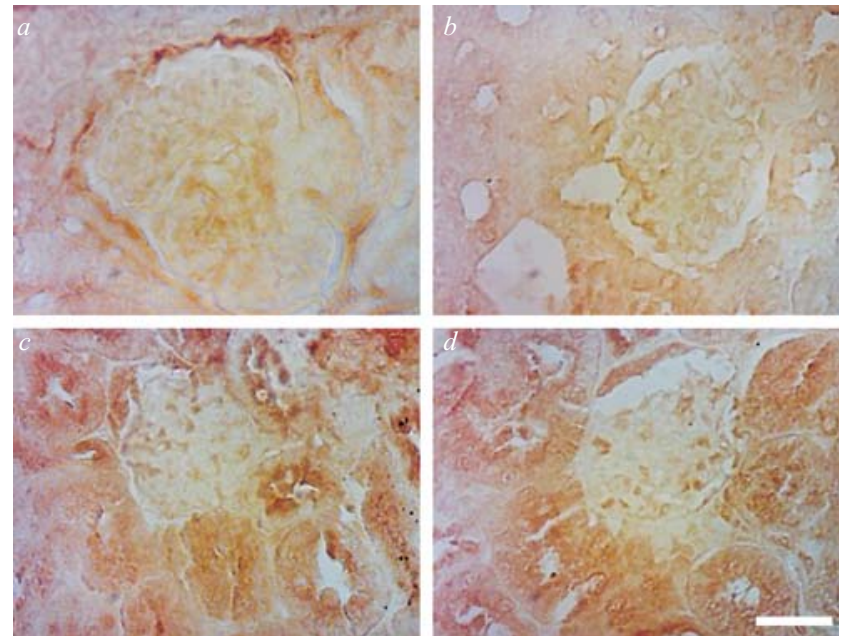

Fig. 4. Localization of PNA receptor sites in renal structures of pttgWT $(a, c)$ and pttg-KO $(b, d)$ mice aged 1 month $(a, b)$ and 1 year $(c, d)$ : increased reactivity of cytoplasmic glycoconjugates in renal tubules of pttg-KO compared to control mice. Objective $40 \times$, scale bar $20 \mu \mathrm{m}$
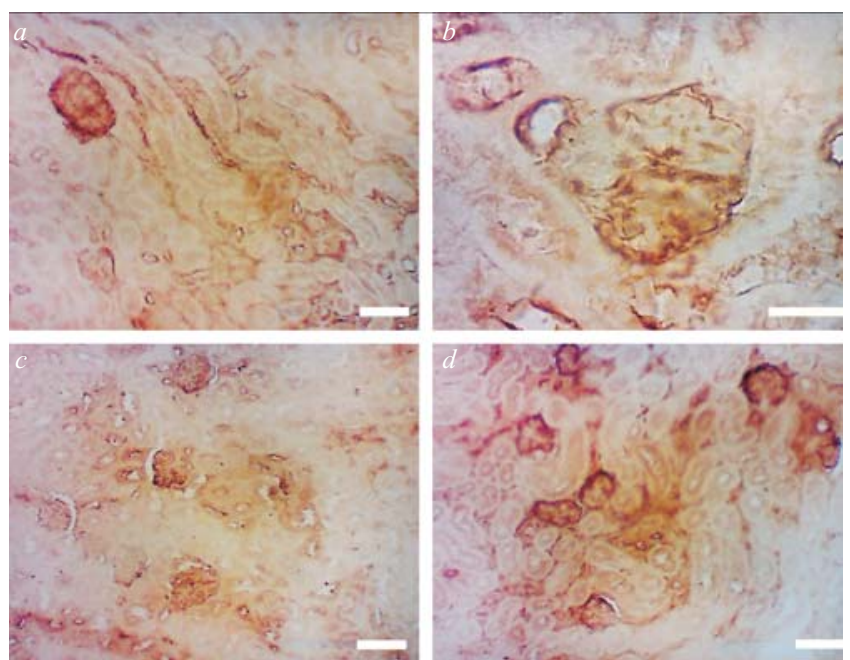

Fig. 6. Selective WGA reactivity with basement membrane of renal corpuscles, moderate reactivity with brush border of renal tubules. Animal groups: pttg-WT $(a, c)$ and pttg-KO $(b, d), 1$ month $(a, b)$ and 1 year $(c, d)$ of age. Objectives $20 \times(a, c, d)$ and $40 \times(b)$, scale bar $20 \mu \mathrm{m}$ 
tes. However, while hypoplasia of spleen and thymic hyperplasia leveled with age, testicular hypoplasia aggravated during sexual maturation of mice [4]. Based on these data, a cell-specific effect of the pttg-derived protein on the proliferative activity was assumed [4].

For all tissues and organs, the actively expressing pttg gene, intense growth and cell division were characteristic. A large quantity of the pttg mRNA was detected in normal cells of adult rat testes and in liver of rat embryos [1], as well as in most mammalian tumor cell lines [2]. In malignant tumors of pituitary gland, the expression of the $\mathrm{pttg}-1$ gene is significantly higher than in the benign tumors of the same organ. Therefore, pttg- 1 is considered as a proto-oncogene whose expression is activated in the malignant growth. This impairs the cell signaling pathways responsible for the regulation of the cell cycle, that indicates the transformation of this gene into an active oncogene.

Apparently, the influence of the pttg- 1 gene product on the qualitative and quantitative composition of the carbohydrate determinants of individual cells of organ tissues is indirect. Analysis of the nucleotide sequence of this gene in mice showed that its promoter site contains the centers for potential binding of several transcription factors, including SP-1, AP-4 and c-Myb [25]. It is known, that SP-1 factor which interacts with the nucleotide sequences rich in $\mathrm{G}$ and $\mathrm{C}$ nucleotides, is involved in regulation of both constitutive, as well as inducible transcription of so-called «house-keeping» genes, as well as tissue-specific regulation of hormoneinducible changes in the expression of several genes [26]. In particular, SP-1 regulates the expression of genes characteristic for erythroid [27], lymphoid [28] and monocyte-like [29] cells.

Conclusions. Presented results indicate a potential role of the pttg- 1 gene products in histophysiology of the urinary system, particularly, in an increased urinary space of the renal corpuscles, and this phenomenon is possibly associated with an increased filtration rate of primary urine. The application of lectins with different carbohydrate specificity showed an important role and vast range of glycoconjugates involved in the formation of both the filtration barrier and in the re-absorption processes. However, a lack of qualitative changes of lectin receptor sites in structural components of kidney in the pttg-deficient mice does not provide direct evidence on the effects of this gene product in processing and exposure of renal carbohydrate determinants. Comparison of lectin binding profiles of renal structures of mice aged one month and one year showed no significant differences. Apparently, that observation indicate that maturation of carbohydrate determinants in kidneys of BL6/C57 strain mice is completed by $30^{\text {th }}$ postnatal day. WGA can be recommended as a selective histochemical marker of the renal corpuscles, and SBAof the renal collecting ducts in mice.

Acknowledgements. The authors are grateful to Dr. Shlomo Melmed (Cedar-Sinai Medical Center, USA) for his help in obtaining the pttg- 1 knockout mice, and Olena Kanyuka - for her assistance with taking care of these laboratory animals.

Нокаут гена $p t t g$ у мишей супроводжується збільшенням сечового простору ниркових тілець

О. Ю. Варивода, А. М. Ященко, О. Д. Луцик, Р. О. Білий, С. В. Афанасьєв, С. З. Філяк, Р. С. Стойка

Резюме

Мета. Дослідити вплив нокауту гена pttg-1 на морфометричні показники і вуглеводні детермінанти структурних компонентів нирки митей. Методи. Тест-об' 'ктом слугували тканини нирки мишей лінї ВL6/C57 з нокаутом гена pttg-1 (pttg-KO) і митей дикого типу (pttg-WT) віком 1 місяць та 1 рік. Морфометричні дослідження проводили за допомогою програмних комплексів аналізу зображень ImagePro Plus ma ImageJ. Вуглеводні детермінанти вивчали з використанням набору з восьми лектинів різної вуглеводної специфічності, мічених пероксидазою, з наступною візуалізачією діамінобензидином. Результати. Встановлено, щяо нокаут гена pttg-1 супроводжується збільшенням сечового простору ниркових тілець у середньому на $30 \%$, підвищеним експонуванням рецепторів лектинів LCA і PNA, а також редукцієє рецепторів LABA, WGA і SNA. Висновки. Отримані результати свідчать про дію продукту гена рttg на процесинг та експонування глікополімерів у структурах нирки, щчо може вплива- ти на прочеси ультрафільтрації первинної сечі.

Ключові слова: дефіцит гена pttg-1, лектинова гістохімія, ниркові тільия, морфометрія, миші.

Нокаут гена pttg у мышей сопровождается увеличением мочевого пространства почечных телец

О. Ю. Варивода, А. М. Ященко, А. Д. Луцик, Р. А. Билый, С. В. Афанасьев, Е. 3. Филяк, Р. С. Стойка

Резюме

Цель. Исследовать влияние нокаута гена pttg-1 на морфометрические параметры и углеводные детерминанты почки мымей. Методы. В качестве тест-объекта использованы ткани почки мышей линии BL6/C57 с нокаутом гена pttg (pttg-KO) и мышей дикого типа (pttg-WT) в возрасте 1 месяи и 1 год. Морфометрические исследования проводили с помощью программных комплексов 
анализа изображений ImagePro Plus и ImageJ. Углеводные детерминанты выявляли с использованием набора из восьми лектинов различной углеводной специфичности, меченных пероксидазой, с последующей визуализацией диаминобензидином. Результаты. Нокаут гена pttg-1 сопровождается увеличением мочевого пространства почечных телеи в среднем на $30 \%$, возрастанием экспонирования рецепторов лектинов LCA и PNA, а также редукичией рецепторов LABA, WGA и SNA. Выводы. Полученные результаты свидетельствуют о действии продукта гена рttg-1 на процессинг и экспонирование гликополимеров в структурах почки, что может влиять на процессы ультрафильтрации первичной мочи.

Ключевые слова: дефицит гена pttg-1, лектиновая гистохимия, почечные тельиа, морфометрия, мыии.

\section{REFERENCES}

1. Pei L, Melmed S. Isolation and characterization of a pituitary tumor-transforming gene (pttg). Mol Endocrinol. 1997; 11(4) 433-41.

2. Zhang X, Horwitz GA, Prezant TR, Valentini A, Nakashima M, Bronstein MD, Melmed S. Structure, expression, and function of human pituitary tumor-transforming gene (pttg). Mol Endocrinol. 1999; 13(1):156-66.

3. Tfelt-Hansen J, Kanuparthi D, Chattopadhyay N. The emerging role of pituitary tumor transforming gene in tumorigenesis. Clin Med Res. 2006; 4(2):130-7.

4. Wang $Z$, Yu R, Melmed $S$. Mice lacking pituitary tumor transforming gene show testicular and splenic hypoplasia, thymic hyperplasia, thrombocytopenia, aberrant cell cycle progression, and premature centromere division. Mol Endocrinol. 2001; 15(11): 1870-9.

5. Kanyuka O, Filyak Ye, Sybirna N. Erythrone functional state in mice with the knockout of pttg gene. Visnyk of L'viv University, Ser Biol. 2011; Is. 56:22-27.

6. Afanasyev S, Filak Y, Stoyka R. Effect of lack of pttg-1 on development of autoimmune processes. Stud Biol. 2011; 5(2):29-36.

7. Zou H, McGarry TJ, Bernal T, Kirshner MW. Identification of a vertebrate sister-chromatid separation inhibitor involved in transformation and tumorigenesis. Science. 1999; 285(5426):418-22.

8. Zur A, Brandeis M. Securin degradation is mediated by fzy and fzr and is required for complete chromatid separation but not for cytokinesis. EMBO J. 2001; 20(4):792-801.

9. Yu R, Ren SG, Horwitz GA, Wang Z, Melmed S. Pituitary Tumor Transfroming Gene ( $p t t g$ ) regulates placental JEG-3 cell division and survival: evidence from live cell imaging. Mol Endocrinol. 2000; 14(8):1137-46.

10. Yu R, Heaney A, Lu W, Chen J, Melmed S. Pituitary tumor-transforming gene (pttg) causes aneuploidy and p53-dependent and p53-independent apoptosis. J Biol Chem. 2000; 275(47): 36502-5.

11. Mei J, Huang $X$, Zhang P. Securin is not required for cellular viability, but is required for normal growth of mouse embryonic fibroblasts. Curr Biol. 2001; 11(15):1197-201.

12. Varyvoda OY., Filyak YuZ, Lutsyk AD, Stoika RS. Mice lacking pituitary tumor transforming gene show elevated exposure of DGalNAc carbohydrate determinants. Biopolym Cell. 2012; 28 (2):129-33.
13. The sugar code: fundamentals of glycosciences / Ed. HJ Gabius Weinheim: John Wiley \& Sons, 2009; 597 p.

14. Varki A, Cummings RD, Esko JD, Freeze HH, Stanley P, Bertozzi CR, Hart GW, Etzler ME. Essentials of glycobiology $/ 2^{\text {nd }}$ ed. Cold Spring Harbor: Cold Spring Harbor Lab. Press, 2009; $586 \mathrm{p}$.

15. Lutsyk AD, Detiuk ES, Lutsyk MD. Lectins in histochemistry Lviv: Vyshcha Shkola, 1989; 144 p.

16. Antonyuk VO. Lectins and their resources. Lviv: Kvart, 2005; 554 p.

17. Sharon N. Lectins: carbohydrate-specific reagents and biological recognition molecules. J Biol Chem. 2007; 282(5):2753-64.

18. Bilyy R, Podhorodecki A, Nyk M, Stoika R, Zaichenko A, Zatryb $G$, Misiewicz J, Strek $W$. Utilization of GaN: $\mathrm{Eu}^{3+}$ nanocrystals for the detection of programmed cell death. Physica E: Low-dimensional Systems and Nanostructures. 2007; 40(6):2096-9.

19. Bilyy R, Tomyn A, Kit Y, Podhorodecki A, Misiewicz J, Nyk M, Strek $W$, Stoika $R$. Detection of dying cells using lectin-conjugated fluorescent and luminescent nanoparticles. Materialwissenschaft Werkstofftechnik Special Issue: Nanoscience and Nanotechnology 2009; 40(4):234-7.

20. Bilyy R, Nemesh L, Antonyuk V, Kit Y, Valchuk I, Havryluk A, Chopyak $V$, Stoika $R$. Apoptosis-related changes in plasma membrane glycoconjugates of peripheral blood lymphocytes in rheumatoid arthritis. Autoimmunity. 2009; 42(4):334-6.

21. Roth J. Lectins for histochemical demonstration of glycans. Histochem Cell Biol. 2011; 136(1):117-30.

22. Lutsyk A, Sogomonian E. Structural, functional, and lectin histochemical characteristics of rat ovaries and endometrium in experimental hyper- and hypothyroidism. Folia Histochem Cytobiol. 2012; 50(3):331-9.

23. Hanai T, Usuda N, Morita T, Nagata T. Light microscopic lectin histochemistry in aging mouse kidney: study of compositional changes in glycoconjugates. J Histochem Cytochem. 1994; 42 (7):897-906.

24. Lutsyk A, Ambarova $N$, Antonyuk $V$. Diabetic alteration versus postnatal maturation of rat kidney glycoconjugates - comparative detection by lectin probes. Folia Histochem Cytobiol. 2013; 51(1):92-102.

25. Wang $Z$, Melmed $S$. Characterization of the murine pituitary tumor transforming gene (pttg) and its promoter. Endocrino-logy. 2000; 141(2):763-71.

26. Briggs MR, Kadonaga JT, Bell SP, Tjian R. Purification and biochemical characterization of the promoter-specific transcription factor, Sp1. Science. 1986; 234(4772):47-52.

27. Yu CY, Motamed K, Chen J, Bailey AD, Shen CK. The CACC box upstream of human embryonic epsilon globin gene binds $\mathrm{Sp} 1$ and is a functional promoter element in vitro and in vivo. $J$ Biol Chem. 1991; 266(14):8907-15.

28. Spanopoulo E, Giguere V, Grosveld F. The functional domains of the murine Thy-1 gene promoter. Mol Cell Biol. 1991; 11(4): 2216-28.

29. Zhang D, Hetherington CJ, Tan S, Dziennis SE, Gonzales DA, Chen H, Tenen DG. Sp1 is a critical factor for the monocytic specific expression of human CD14. J Biol Chem. 1994; 269(15): 11425-34. 